\title{
PENGEMBANGAN POTENSI WISATA ALAM SECARA SPASIAL DESA BONGO KECAMATAN BATUDAA PANTAI KABUPATEN GORONTALO Spatial Natural Tourism Potential Development of Bongo District of Batudaa Pantai Gorontalo Regency
}

\author{
Titin Umi Rahayu ${ }^{1}$, Ahmad Syamsu Rijal S ${ }^{1}$, Ivan Taslim ${ }^{1}$ \\ ${ }^{1,2,3}$ Program studi Geografi Universitas Muhammadiyah Gorontalo, Indonesia \\ Email Korespondensi: titinumirahayu96@gmail.com
}

DOI: http://dx.doi.org/10.31314/jsig.v3i1.347

Abstract - The purpose of this study is to analyze the development of spatial natural tourism potential and identification of Bongo torism potential using SWOT analysis. By usung a qualitative descriptive method and data source in the from of primary and secondary data. Primary data covering field observation, interview and secondary data covering the map of RBI 1: 25.000, satellite image of Google Maps and data of visitor number which then described by SWOT matrix. The result of this study indicate the Bongo village has good natural tourism potential to be developed, in terms of attractiveness with the hills are very beautiful types of taours that can be developed that is a natural panorama taour and outbound tourism other than that Bongo village has a Dulanga beach with coral reef and other merine biota with a decent tour to be developed that is snorkeling tour. As for supporting facilities and infrastructure of natural attractions Bongo village needs to be added in order to meet the needs of tourist who visit because wih adequate faciliteis and infrastructure can increase the number of tourists both local and foreign.

Keywords: spatial development, natural tourism, bongo tourism.

\begin{abstract}
Abstrak - Penelitian ini bertujuan untuk menganalisa pengembangan potensi wisata alam secara spasial danidentifikasi potensi wisata Bongo menggunakan analisis SWOT. Dengan menggunakan metode deskriptif kualitatif dan sumber data berupa data primer dan sekuder. Data primer yang meliputi observasi lapangan, wawancara dan data sekunder yang meliputi peta RBI 1:25.000, citra satelit google Map serta data jumlah pengunjung yang kemudian di deskripsikan melalui matrik SWOT. Hasil penelitian ini menunjukkan bahwa desa Bongo memiliki potensi wisata alam yang baik untuk dikembangkan, dari segi daya tarik dengan perbukitan yang sangat indah jenis wisata yang dapat dikembangkan yakni wisata panorama alam dan wisata outbond selain itu desa Bongo memiliki pantai dulanga dengan terumbu karang dan biota laut lainya dengan wisata yang layak untuk dikembangkan yaitu wisata snorkling. Sedangkan untuk sarana dan prasarana penunjang obyek wisata alam Desa Bongo perlu ditambahkan agar dapat memenuhi kebutuhan wisatawan yang berkunjung karena dengan sarana dan prasarana yang memadai dapat meningkatkan jumlah wisatawan baik lokal maupun mancanegara
\end{abstract}

Kata kunci: pengembangan spasial, wisata alam, wisata bongo. 


\section{PENDAHULUAN}

Indonesia merupakan negara dengan kekayaan alam dengan wisata yang melimpah menjadikan Indonesia sebagai salahsatu Negara tujuan wisata dunia. Dengan kondisi kekayaan alam dan wisata yang sangat banyak tersebut maka banyak pula potensi wisata yang dimiliki oleh Indonesia. Kekayaan wisata ini hendaknya mampu dikelola secara optimal untuk meningkatkan pendapatan masyarakat pada khususnya dan devisa Negara pada umunya. Dalam upaya pengembangan pariwisata Indonesia, maka sangat banyak kendala yang dihadapi, sehingga perkembangannya tidak merata dan seimbang. Hal ini tidak lepas dari peran pemerintah yang kurang dalam pengembangan dan pengelolaan kawasan wisata di beberapa daerah. Begitu pula dengan wisata yang ada di Kecamata Batuda'a Pantai, Desa Bongo Kabupaten Gorontalo potensi wisata alam yang belum dikembangkan secara maksimal.

Desa Bongo Kecamatan Batuda'a Pantai merupakan salahsatu desa yang ada di Provinsi Gorontalo selain memiliki potensi wisata berbasis budaya, desa ini memiliki potensi alam yang bagus untuk dikembangkan. Sehingga obyek wisata Desa Bongo perlu memanfaatkan potensi alam yang ada dan pengembangan potensi alam yang dilakukan baik dari segi antraksi (daya tarik), amenitas (pelayanan) dan aksesibilitas (keterjangkauan). Karena terbatasnya fasilitas pendukung potensi alam menjadi hambatan pelaksanaan kegiatan pariwisata di Desa Bongo. Wisatawan masih ragu untuk mengunjungi atau pun berlama-lama berada di desa ini, karena segala sesuatu yang mereka butuhkan belum tersedia. Hal ini juga yang dapat memicu rendahnya angka wisatawan yang berkunjung kembali atau repeater tourist. Berdasarkan penjelasan tersebut maka perlu dilakukan penelitian tentang Pengembangan potensi wisata alam secara spasial desa bongo.

Desa Bongo Kecamatan Batudaa Pantai Kabupaten Gorontalo. Secara geografis desa Bongo terletak diantara 00 30' 37.00" LU dan 1230 01'31.24" BT. Secara administrasi Desa Bongo berbatasan dengan Kelurahan Tenilo di bagian utara, teluk tominibagian selatan, kelurahan Pohe (Dudetumo) Kota Gorontalobagian timur, Tanjung Pangatiboni bagian barat. Desa bongo merupakan sebuah desa yang berada di pesisir teluk tomini dan memiliki dua wilayah yaitu wilayah dataran tinggi yang bernama Tapa Modelo (sekarang menjadi dusun Tenilo dan dusun Wapalo) dan wilayah dataran rendah bernama Tapa Huota dan Huwata (sekarang menjadi dusun timur, dusun tengah dan dusun barat). Sumber mata pencaharian penduduk Desa Bongo yaitu petani dan nelayan. Desa ini merupakan salahsatu desa wisata yang akan dikembangkan sebagai desa wisata berbasis masyarakat menurut Peraturan Daerah Provinsi Gorontalo Pasal 14 Nomor 2 Tahun 2014 tentang kebijakan destinasi pariwisata.

\section{METODE DAN DATA}

Penelitian di wisata alam Desa Bongo dilakukan untuk mengembangkan potensi wisata alam yang ada di Desa ini dengan menggunakan metode kualitatif dengan sumber data yaitu data primer dan data sekunder. Data primer dalam penelitian ini adalah data survei, observasi, wawancara, serta dokumentasi. Dimana metode survei, menurut Sugiono (2013) digunakan untuk mendapatkan data dari temapat tertentu yang alamiah (bukan buatan). Pengumpulan data melalui observasi adalah pengamatan langsung ke lokasi penelitian dan melakukan kegiatan pencatatan berbagai jenis data yang meliputi (1) Antraksi wisata yakni semua daya tarik wisata di kawasan wisata Desa Bongo Kecamatan Batuda'a Pantai. (2) Amenitas, adalah data yang berupa fasilitas dan infrastruktur yang ada seperti warung, WC umum, mesjid walima dan sebagainya. (3) Aksesibilitas, yaitu data yang berkaitan dengan kemudahan menjangkau obyek wisata. Adapun tehnik wawancara dimana pengumpulan data dengan cara mengadakan interaksi dan komunikasi antara peneliti dan informan seperti pihak-pihak atau orang-orang yang mengetahui keadaan wisata bongo dengan menggunakan kuesioner. Sedangkan dokumentasi merupakan tehnik yang digunakan untuk mengumpulkan data berupa data-data pengunjung wisata bongo, adat istiadat dan peninggalan-peninggalan bersejarah. Sedangkan data sekunder merupakan data yang diambil oleh instansi terkait seperti Dinas Pariwisata. 
Tehnik analisis data yang digunakan berupa analisis sapsial dan analisis SWOT menjadi pendukung dalam penelitian ini. Analisis spasial untuk pengembangan potensi wisata alam desa Bongo dilakukan dengan cara menggunakan tabel standar kriteria menjadi daerah tujuan wisata dari Yoeti dan kriteria penilaian potensi pariwisata berdasarkan parameter fisisk dari Gunn dan Coppock dengan penggunaan sistem buffer dari Pramudia serta analisis geomorfologi dari Van Zuidam dalam bermana. Analisis ini akan menghasilkan beberapa peta seperti peta atraksi wisata, peta geomorfologi, peta penggunaan lahan, peta sarana dan prasarana penunjang pariwisata, dan peta aksesibilitas sehingga dapat dijadikan sebagai informasi dalam pengembangan wisata alam Desa Bongo kedepannya. Analisis SWOT ini digunakan untuk mengetahui kekuatan, kelemahan, ancaman dan peluang dalam pengembangan wisata alam Desa Bongo yang dilihat dari segi potensi wisata baik dari daya tarik (antraksi), pelayanan (amenitas), dan keterjangkauan untuk menepuh wisata tersebut (aksesibilitas) agar bisa menjadikan wisata alam Desa Bongo lebih berkembang dan dikenal oleh wisatawan baik lokal maupun manca negara.

\section{HASIL DAN PEMBAHASAN}

Atraksi Wisata
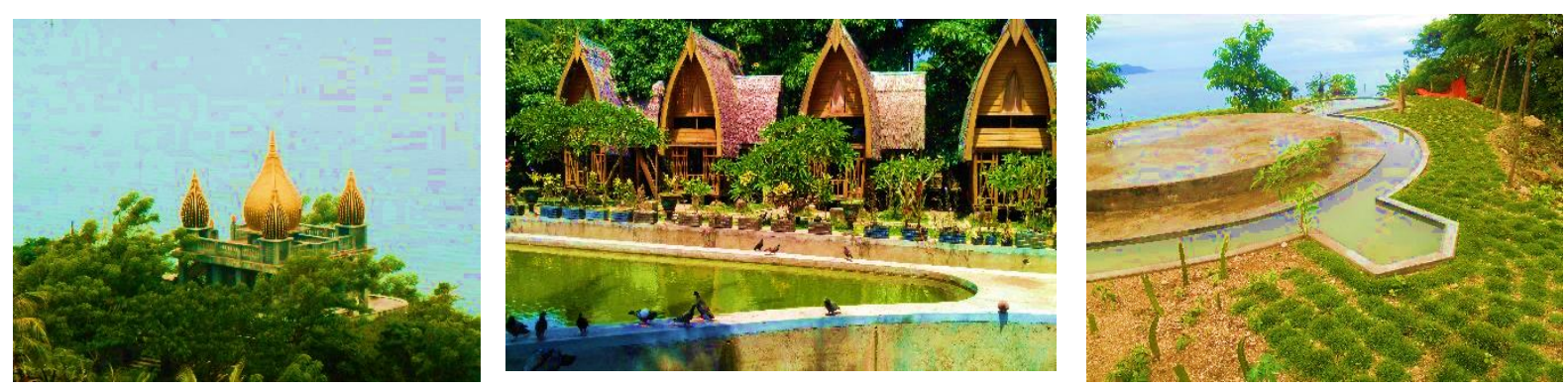

Gambar 2. Obyek Wisata Desa Bongo

Atraksi atau daya tarik wisata adalah segala sesuatu yang memiliki keunikan, keindahan, kemudian nilai yang berupa keanekaragaman kekayaan alam, budaya, dan hasil buatan manusia yang menjadi sasaran atau tujuan kunjungan wisatawan. Desa wisata Bongo sendiri memiliki tiga obyek yang menjadi daya tarik bagi wisatawan yaitu, pada pesantren alam bubohu secara astronomisnya tertelatak di $0^{\circ} 29^{\prime} 56.90^{\prime \prime}$ lintang utara dan $123^{\circ} 2^{\prime} 1.64^{\prime \prime}$ bujur timur, masjid walima emas yang terletak di $0^{\circ} 29^{\prime} 54.91^{\prime \prime}$ lintang utara dan $123^{\circ} 1^{\prime} 45.58^{\prime \prime}$ bujur timur, dan petilasan terletak di $0^{\circ} 30^{\prime} 1.39^{\prime \prime}$ lintang utara dan $123^{\circ}$ 1'41.03" bujur timur.

Ke tiga obyek wisata tersebut yang menjadi daya tarik dari wisata desa Bongo dapat dilihat pada gambar 3 tentang obyek wisata desa Bongo dan pada gambar 3 mengenai peta atraksi wisata desa Bongo.

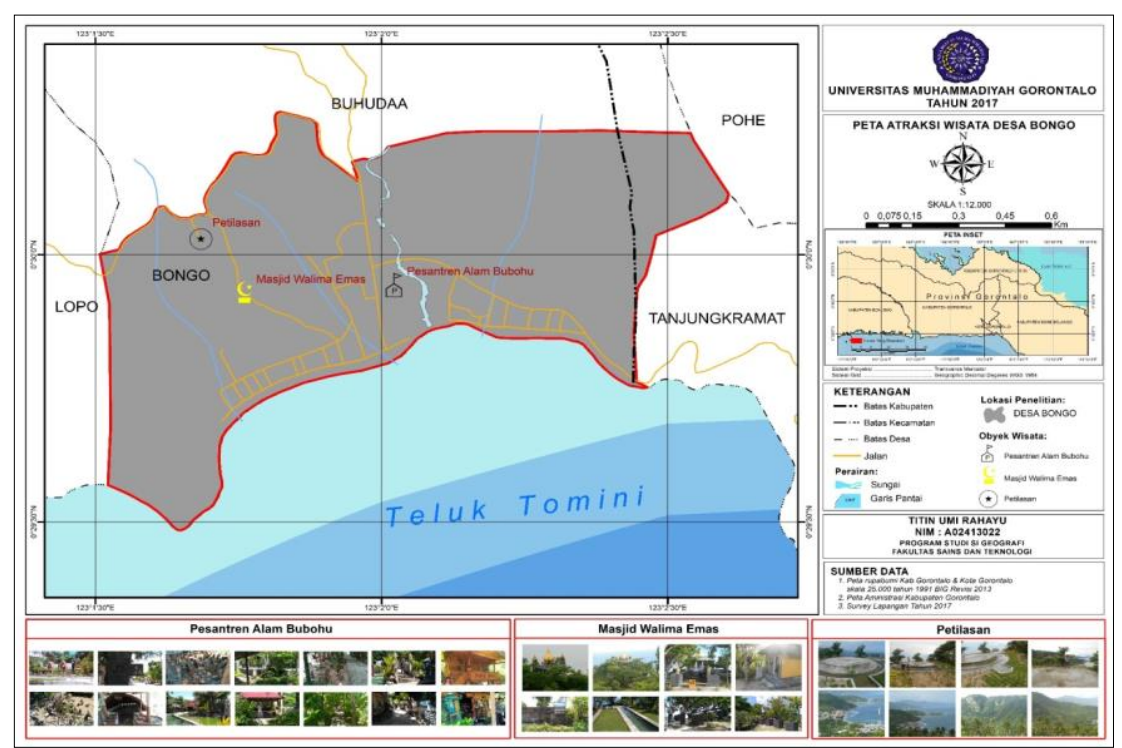

Gambar 1. Peta Atraksi Wisata Desa Bongo 


\section{Analisis Geomorfologi}

Peta geomorfologi ini Tabel 1. Interval Ketinggian dianalisis dari citra Aster Global DEM Tahun 2016 yang di unduh dari website (https://earthexplorer.usgs.gov ). Dengan melihat tabel 1 tentang hubungan ketinggian absolut dengan morfografi menurut Van Zuidam maka dalam pembagian interval

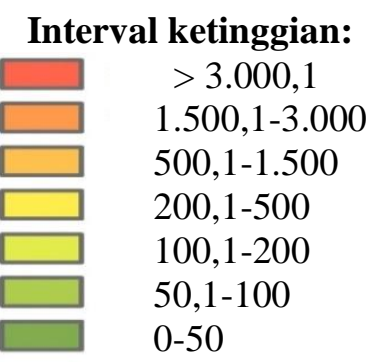

\author{
Unsur Morfografi: \\ Pegunungan tinggi \\ Pegunungan \\ Perbukitan tinggi \\ Perbukitan \\ Perbukitan rendah \\ Dataran rendah pedalaman \\ Dataran rendah
}

ketinggian dibagi menjadi 7 kriteria dari 0-50 mdpl, dimana setiap intervalnya memiliki selisi ketinggian $50 \mathrm{mdpl}$. Interval ketinggiannya yaitu 0-50 merupakan dataran rendah, 50,1-100 merupakan dataran rendah pedalaman, 100,1-200 merupakan perbukitan rendah, 200,1-500 merupakan perbukitan, 500,1-1.500 merupakan perbukitan tinggi, 1.500,1-3.000 merupakan pegunungan, >3.000,1 merupakan pegunungan dengan gradasi warna merah sampai dengan warna hijau tua. Seperti pada tabel 1.

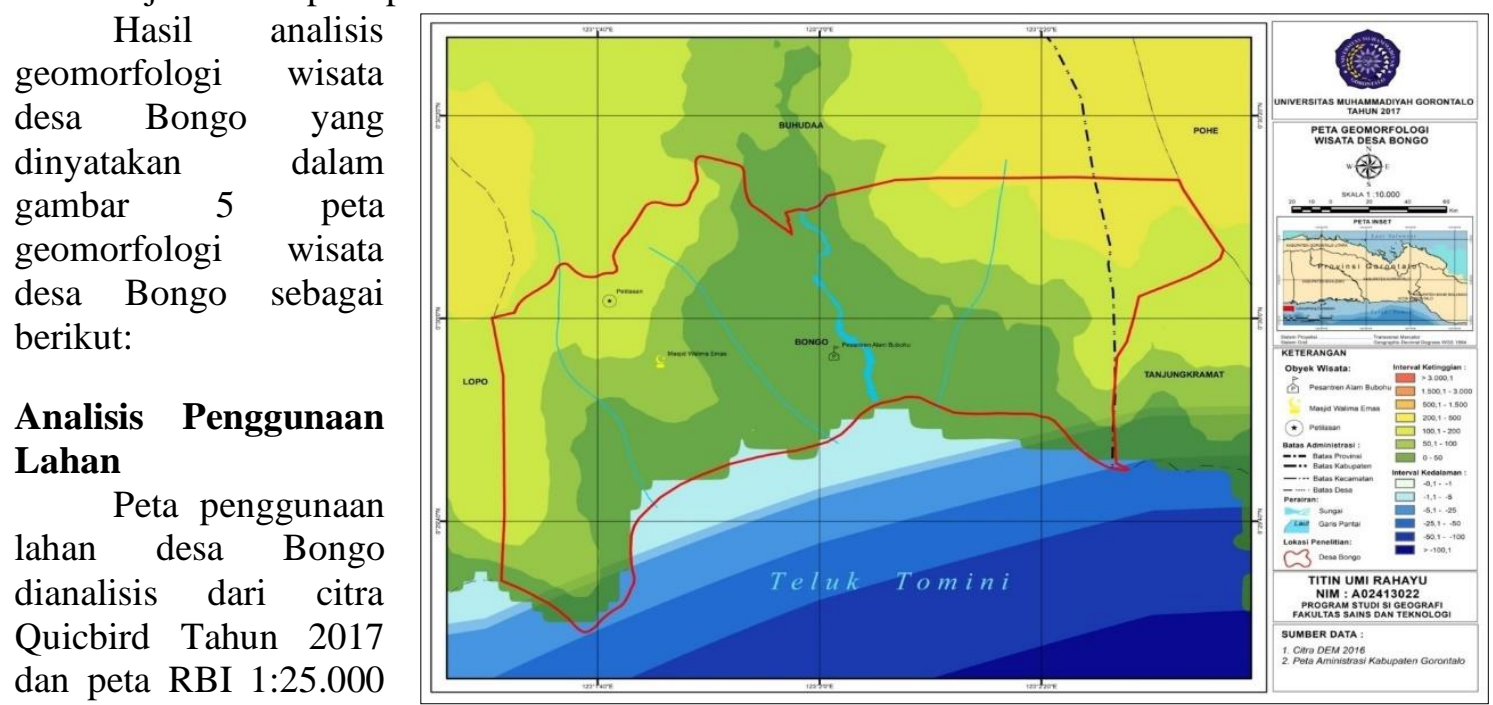

Gambar 3. Peta Geomorfologi Desa Bongo

Tahun 1991 Revisi 2013

Badan Informasi

Geospasial (BIG). Desa

Bongo memiliki 6 jenis penggunaan lahan yaitu penggunaan lahan untuk pemukiman, penggunaan lahan untuk perkebunan/kebun, penggunaan lahan untuk hutan rimba, penggunaan lahan untuk pesisir pantai, penggunaan lahan untuk semak belukar/alang-alang, dan penggunaan lahan untuk tegalan/ladang.

Selain itu, Penggunaan lahan untuk obyek wisata pesantren alam bubohu berada pada area pemukiman warga desa Bongo, dan untuk obyek wisata masjid walima berada pada area semak belukar sedangkan untuk obyek wisata petilasan yang sekarang masih dalam Tabel 2. Penggunaan Lahan

\begin{tabular}{clc}
\hline NO. & \multicolumn{1}{c}{ PENGGUNAAN LAHAN } & LUAS/ha \\
\hline 1 & Hutan & 24,21549723 \\
\hline 2 & Semak Belukar / Alang Alang & 21,32650292 \\
\hline 3 & Tegalan / Ladang & 41,89244734 \\
\hline 4 & Perkebunan / Kebun & 52,53738705 \\
\hline 5 & Permukiman dan Tempat Kegiatan & 23,01954679 \\
\hline 6 & Pesisis pantai & 1,409403277 \\
\hline \multicolumn{2}{c}{ TOTAL } & 164,4007846 \\
\hline
\end{tabular}

proses pembangunan berada pada area perkebunan/kebun. 


\section{Berdasarkan \\ tabel 2 menunjukan luas penggunaan lahan (ha) Desa Bongo dengan jumlah total 164,400, dan penggunaan lahan paling luas yaitu perkebunan/kebun dengan luas 52,235 ha, dimana dengan kondisi bentangalam perbukitan sehingga penggunaan lahan di Desa Bongo lebih dominan perkebunan.} Selain itu, penggunaan

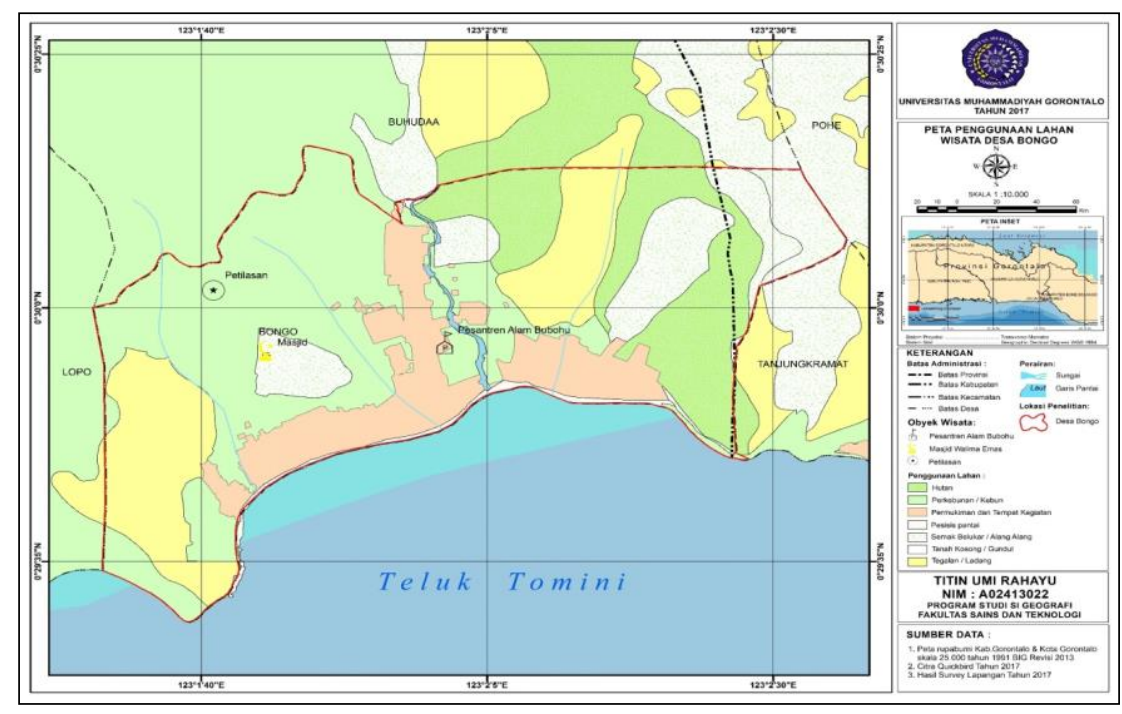

Gambar 4. Peta Penggunaan lahan Desa Bongo lahan untuk daerah pemukiman dan tempat kegiatan dengan luas 23,019 ha, dan untuk luas penggunaan lahan pesisir pantai 1,409 ha, dengan jumlah total yang paling sempit. Sedangkan penggunaan lahan obyek wisata alam Desa Bongo untuk pesisir pantai memiliki panjang pantai 1,21 Km dengan lebar pantai hanya 2-3 Meter dari garis pantai dan sudah merupakan area pemukiman terlihat pada gambar 6 tentang peta penggunaan lahan wisata desa Bongo.

\section{Analisis Sarana dan Prasaranan}

Penentuan

sarana dan prasarana penunjang obyek wisata desa Bongo dengan melihat teori Yoeti dalam standar kelayakan menjadi daerah tujuan wisata dan teori modifikasi model Gunn dan Coppock dalam kriteria penilaian potensi pariwisata berdasarkan

parameter fisik serta teori Pramudia dalam pemakaian

buffer/penyangga untuk penentuan sarana dan prasarana penunjang obyek wisata. Mengadopsi dari teori-teori tersebut, maka jenis sarana dan prasarana yang diidentifikasi pada radius tertentu dari objek wisata adalah: hotel/penginapan, fasilitas kesehatan (puskesmas dan rumah sakit), pos polisi, rumah makan, rumah ibadah, bank/ATM, pasar dan terminal. Perhitungan jumlah dan jenis sarana dan prasarana berdasarkan radius $1-6 \mathrm{~km}$ dari objek wisata dilakukan dengan menggunakan tools aplikasi Sistem Informasi Geografis yaitu buffer. Pembuatan buffer dengan jarak $1 \mathrm{~km}$ pada masing-masing objek wisata, dimaksudkan untuk menganalisis jumlah dan jenis sarana dan prasarana yang berada dalam polygon hasil buffer tersebut. Adapun penambahan wilayah buffer dilakukan apabila sarana dan prasarana pada wilayah tertentu belum mencapai kriteria penunjang sarana dan prasarana obyek wisata tersebut. hasil penilaian dan perhitungan berdasarkan wilayah buffer sarana dan prasarana penunjang pariwisata desa Bongo dapat dilihat pada gambar 5 . 


\section{Analisis Aksesibilitas}

Aksesibiltas ini bertujuan untuk menjangkau suatu lokasi obyek wisata. Untuk menjangkau obyek wisata desa bongo akses jalannya saat ini cukup mudah dijangkau dengan menggunakan kendaraan bermotor, karena wisatawan hanya membutuhkan waktu 30 menit dari pusat kota gorontalo untuk sampai ke tempat wisata. Selain itu akses yang terdapat pada obyek wisata Bongo yakni jalan lokal, jalan lain, dan jalan setapak. Jalan lokal merupakan jalan umum yang berfungsi melayani angkutan setempat dengan ciri perjalanan jarak dekat, kecepatan rata-rata rendah dan jumlah jalan masuk tidak dibatasi. Ada dua jenis jalan lokal yaitu jalan lokal primer dan jalan lokal sekunder. Selain itu untuk objek wisata Desa Bongo itu sendiri yaitu jalan lokal primer. Jalan lain merupakan jalan yang digunakan untuk menjangkau objek wisata masjid walima emas yang terdapat atas bukit dengan panjang $\pm \quad 100$ meter. Sedangkan untuk jalan setapak merupakan jalan yang digunakan untuk menjangkau objek wisata petilan dengan panjang \pm 50 meter serta menjadi penghubung dengan jalan lokal yang ada di desa Bongo.

Hasil analisis aksesibilitas wisata desa Bongo yang dinyatakan dalam gambar 6 peta aksesibilitas wisata

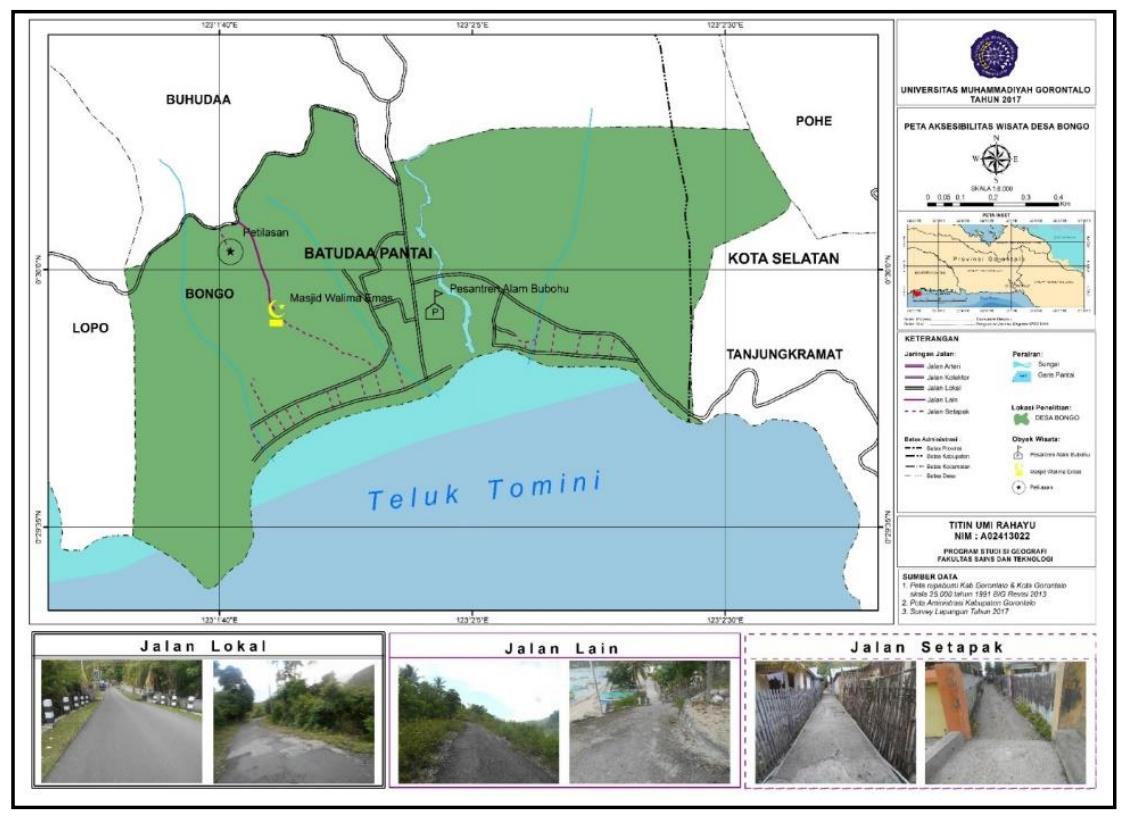

Gambar 6. Peta Aksesibilitas Wisata Desa Bongo desa Bongo.

\section{Analisis faktor internal dan eksternal dalam analisis SWOT}

1. Kekuatan (Strengths)

a. Memiliki panorama alam yang sangat indah

b. Harga tiket masuk tidak ada

c. Memiliki atraksi budaya walima yang unik.

d. Memiliki pantai dengan terumbu karang yang bagus

e. Perbukitan desa Bongo bisa dijadikan sebagai wisata panorama alam dan wisata outbond

2. Kelemahan (Weaknesses)

a. Kurangnya minat/perhatian masyarakat terhadap pengembangan parwisata pantai

b. Kurangnya infrastruktur yang menunjang pariwisata

c. Rendahnya sumber daya masyarakat local

d. Tidak adanya bantuan dari pemerintah

3. Peluang (Oppurtunities)

a. Memperluas lapangan kerja dan usaha masyarakat Desa Bongo

b. Tingginya minat wisata alam

c. Adanya peraturan Daerah Provinsi Gorontalo Pasal 14 Nomor 2 Tahun 2014 tentang wisata berbasis masyarakat yang akan dikembangkan di Desa Bongo

4. Ancaman (Threats)

a. Perkembangan objek wisata lain di Kabupaten Gorontalo

b. Pengaruh budaya luar

c. Persaingan produk wisata dengan tempat wisata lain di Kabupaten Gorontalo

d. Ketergantungan yang berlebihan pada pariwisata. 


\section{Arahan Pengembangan Wisata Alam Desa Bongo}

Pengembangan potensi wisata alam desa Bongo dapat dilihat dengan kondisi bentang alam perbukitan yang sangat indah dan pantai dulanga dengan pesona alamnya yang eksotik sehingga jenis wisata yang dapat dikembangkan dikawasan ini yaitu:

1. Wisata Panorama Alam

Kegiatan mengamati dan menikmati indahnya panorama alam yang terdapat di perbukitan Desa Bongo. Pemandangan yang dapat diamati di dalam kawasan pada jalur tracking yang dilalui dalam melakukan penjelajahan hutan terlihat beraneka jenis vegetasi yang merupakan suatu pemandangan yang mempunyai daya tarik tersendiri bagi para petualangan atau penjelajah.

\section{Wisata Snorkling \\ Melihat kondisi} pantai desa Bongo dari citra Quicbird dimana dengan gradasi warna laut yang biru tua bertanda laut dalam, hanya beberapa meter sudah terlihat dari bibir pantai. Kemudian berdasarkan hasil survey dilapangan memperkuat bahwa obyek wisata alam desa Bongo kondisi pantainya tidak layak

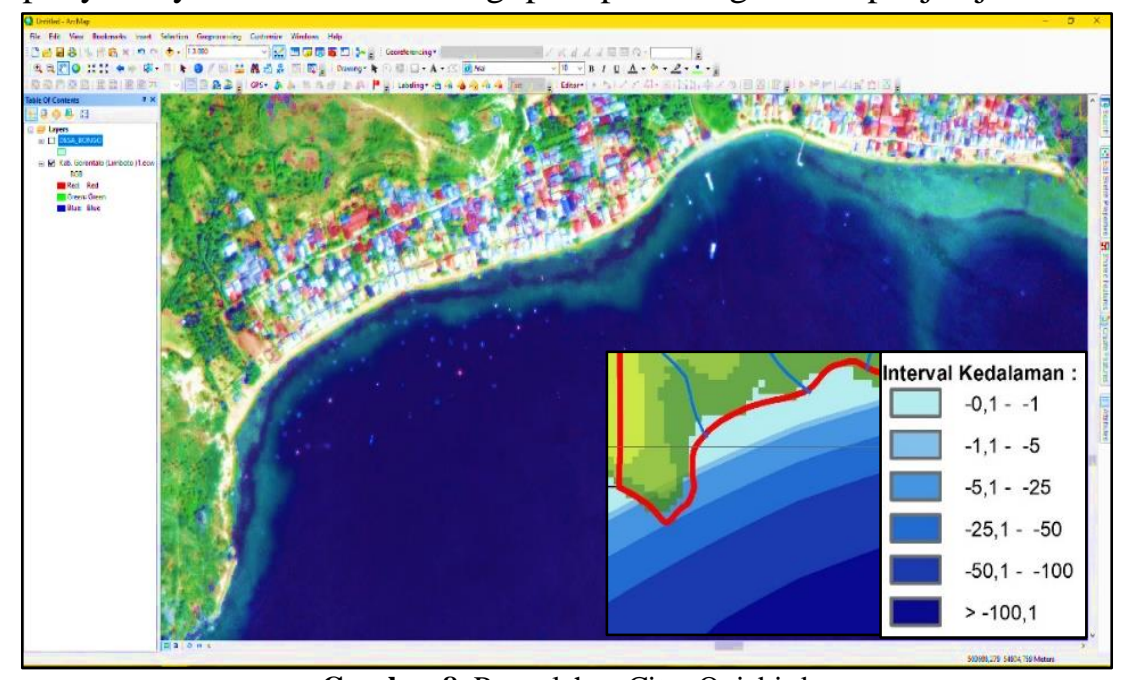

Gambar 8. Pengolahan Citra Quicbird dijadikan sebagai obyek wisata rekreasi pantai, tetapi bisa digunakan sebagai wisata snorkling karena dari sisi timur dan sisi barat pantai memiliki terumbu karang yang berpotensi sebagai tempat snorkling dimana berdasarkan hasil survey dan kondisi geomorfologi dengan kedalaman \pm 1 meter kita dapat melihat terumbu

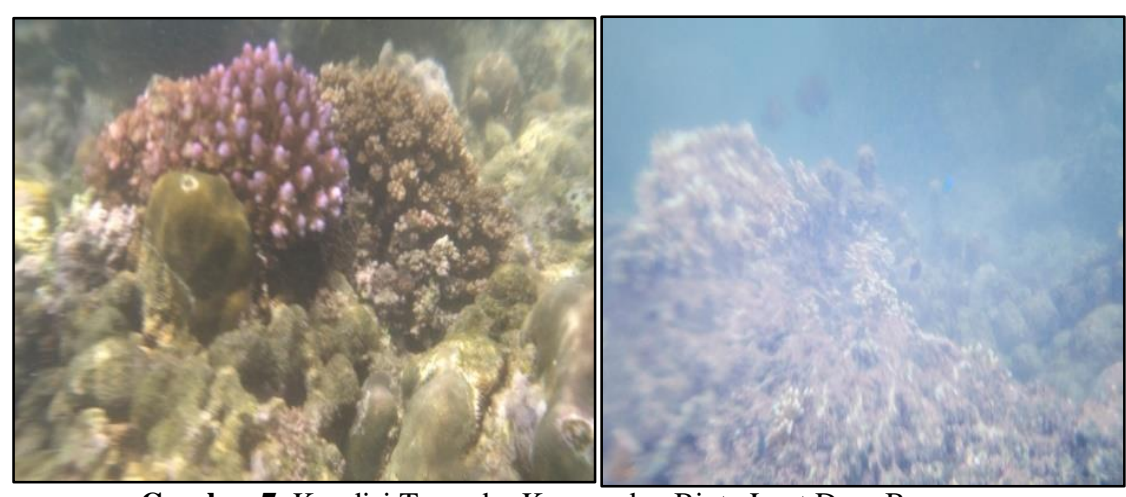

Gambar 7. Kondisi Terumbu Karang dan Biota Laut Desa Bongo

karang dan berbagai jenis biota laut lainya. Selain itu tempat tersebut bisa dijadikan sebagai tempat memancing.

\section{Wisata outbond}

Desa Bongo merupakan sebuah Desa dengan bentang alam yang dominan perbukitan sehingga pada blok pemanfaatan intensif terdapat tapak yang cocok untuk outbond. Pada tapak tersebut dapat dijadikan sebagai sebagai kegiatan flying fox dan pembuatan canopy trail sambil menikmati view perbukitan dataran rendah dan hamparan laut yang sangat indah.

Selain itu perkembangan pariwisata suatu daerah tidak terlepas dari ketersediaan prasarana dan sarana objek wisata. Prasarana dan sarana wisata yang lancar merupakan salahsatu indikator serta unsur strategis dalam mewujudkan pertumbuhan dan perkembangan kepariwisataan. Banyaknya variasi sarana dan prasarana, kelengkapan sarana dan prasarana, serta keamanan dan kenyaman lingkungan menjadi daya tarik tersendiri bagi wisatawan yang berkunjung. Wisata Bongo merupakan wisata yang masih kurang sarana dan prasarana penunjang sehingga, perlu dilakukan penambahan fasilitas agar wisatawan yang berkunjung lebih meningkat. 
Adapun arahan pengembangan sarana dan prasarana wisata bongo dapat dilakukan dengan halhal berikut:

1. Rumah makan

2. Penginapan/hotel

3. Keamanan

4. Toko suvenir

Fasilitas untuk rumah makan/restoran, penginapan/hotel, keamanan, dan toko suvenir yang ada di Desa Bongo belum tersedia sehingga, wisatawan yang berkunjung di tempat ini masih ragu-ragu untuk tinggal lebih lama karena segala sesuatu yang mereka butuhkan belum tersedia ditempat ini.

\section{KESIMPULAN}

Berdasarkan hasil penelitian dan pembahasan di atas, maka dapat di simpulkan Analisa pengembangan potensi wisata alam secara spasial Desa Bongo Kecamatan Batuda'a Pantai Kabupaten Gorontalo dikaji secara spasial yaitu untuk melihat daya tarik, dari sisi geomorfologi desa Bongo memiliki perbukitan yang bagus untuk dikembangkan dengan wisata panorama alam, dan wisata outbond. Selain itu pantai dulangan yang ada di Desa Bongo yang mempunyai keindahan terumbu karang dan biota laut lainnya yang bisa dijadikan sebagai obyek wisata snorkling. Sehingga untuk menunjang perkembangan obyek wisata alam desa Bongo melihat dari sisi sarana prasarana objek wisata dan aksesibilitas.

Hasil identifikasi menggunakan matriks SWOT, dapat dirumuskan strategi inti untuk pengembangan wisata Desa Bongo untuk meningkatkan jumlah kunjungan wisatawan sebagai berikut:

a. Strategi SO. Strategi SO merupakan strategi yang menggunakan kekuatan untuk memanfaatkan peluang yang menghasilkan strategi merancang paket antraksi wisata seperti paket antraksi budaya walima dan paket wisata pantai serta meningkatkan dan mengembangkan usaha kecil sebagai basis penghidupan bagi masyarakat desa Bongo.

b. Strategi ST. Strategi ST merupakan strategi yang menggunakan kekuatan untuk mengatasi ancaman yang menghasilkan strategi peningkatan pelayanan wisata dan meluncurkan promo-promo wisata desa Bongo.

c. Strategi WO. Strategi WO merupakan strategi yang meminimalkan kelemahan untuk memanfaatkan peluang yang menghasilkan strategi peningkatan jumlah fasilitas desa Bongo yang memadai dan peningkatan promosi melalui berbagai media.

d. Strategi WT. Strategi WT merupakan strategi yang meminimalkan kelemahan dan menghindaro ancaman yang menghasilkan strategi menjalin kerjasama antara pengelola dan pemerintah agar lebih meningkatkan fasilitas obyek wisata yang memadai di desa Bongo serta menjalin kerjasama dengan obyek wisata lain yang ada di Kabupaten Gorontalo untuk membangun rute wisata.

\section{DAFTAR PUSTAKA}

Bermana, I., 2006. Klasifikasi Geomorfologi Untuk Pemetaan Geologi. Jurnal Bulletin of Scientific Contribution. Volume 4 Nomor 2

Demolingo, R, H., 2015. Strategi Pengembangan Destinasi Wisata Desa Bongo Kabupaten Gorontalo. Jurnal Pariwisata.Volume 1 Nomor 2

Dian, K., 2009. Persepsi Wisatawan Nusantara Terhadap Daya Tarik Wisata Di Kota Palembang. Yokyakarta. Universitas Gadjah Mada. Tesis

Ismanto, D., 2007. Analisis Tingkat kepuasan Wisatawan di ODTW Kaliurang dalam Upaya Peningkatan Kualitas Produk dan Layanan Wisata, Yogyakarta: Universitas Gadjah Mada. Tesis

Maulana, A., 2014. Strategi Pengembangan Wisata Spiritual di Kabupaten Bagung, Provinsi Bali. Jurnal Kepariwisataan Indonesia. Volume 9 Nomor 2

Nugroho, P, A., 2010. Perencanaan Pariwisata Alam Berbasis Data Spasial Di Taman Nasional Bukit Barisan Selatan. Bogor. Institut Pertanian Bogor. Tesis

Peneliti PMB-LIPI. 2006. Sarana dan Prasarana Pariwisata. http:/file.upi.edu/Direktori/FPIPS/JUR.PEND.GEOGRAFI/Kriteria Prasarana dan Sarana Pariwisata. pdf. Diakses pada tanggal 12 Mei 2016 
Pramudia, E. 2008., Evaluasi Potensi Obyek Wisata Aktual di Kabupaten Agam Sumatera Barat Untuk Perancangan Program Pengembangan. Bogor. Institut Pertanian Bogor. Tesis

Peraturan Daerah ( PERDA ) Provinsi Gorontalo Pasal 13 Huruf A Nomor 2 Tahun 2014 Tentang Rencana Induk Pembangunan Pariwisata Daerah (RIPPDA ) Provinsi Gorontalo. 2014. Gorontalo

Prahasta, E., 2007. Konsep-konsep Dasar Sistem Informasi Geografis. Bandung: Informatika

Ramly, N., 2007. Pariwisata Berwawasan Lingkungan. Jakarta: Grafindo Khazanah Ilmu.

Rangkuti, F., 2006. Analisis SWOT. Teknik Membedah Kasus Bisnis. Cetakan Kedua Belas. Jakarta: PT Gramedia Pustaka Utama.

Su Ritohardoyo, 2013. Penggunaan dan Tata Guna Lahan. Ombak. Yogyakarta.

Sugiono, 2009. Metode Penelitian Kuantitatif dan Kualitatif. Bandung: Alfabeta

Sugiono, 2013. Metode Penelitian Pendidikan: Bandung. Alfabeta

Sinaga, S., 2010. Potensi dan Pengembangan Objek Wisata Di Kabupaten Tapanuli Tengah. Kertas Karya. Program DIII Pariwisata. Universitas Sumatera Utara.

Undang-Undang Republik Indonesia Nomor 10 Tentang Kepariwisataan. 2009. Jakarta

Undang-Undang Republik Indonesia Nomor 4 Tentang Informasi Geospasial. 2011. Jakarta

Peraturan Pemerintah Republik Indonesia Nomor 36 Tentang Pengusahaan Pariwisata Alam Di Suaka Margasatwa, Taman Nasioanal, Taman Hutan Raya, Dan Taman Wisata Alam. 2010. Jakarta

Peraturan Menteri Kehutanan Republik Indonesia Nomor P.48/Menhut-II Tentang Pengusahaahn Pariwisata Alam Di Suaka Margasatwa, Taman Nasional, Taman Hutan Raya Dan Taman Wisata Alam. 2010.Jakarta

Yoeti, O., 2007. Perencanaan dan Pengembangan Pariwisata. Jakarta: PT Pradya Paramita Yoeti, O., 2008. Anatomi Pariwisata. Bandung. Penerbit Angkasa

Yoeti, O., 1996. Pengantar Ilmu Pariwisata. Bandung. Penerbit Angkasa 